\title{
Influence of Lithium on Nanosized Films of $\mathrm{Fe}_{2} \mathrm{O}_{3}$
}

\author{
A. Turković, ${ }^{1}$ M. Ivanda, ${ }^{1}$ M. Bitenc, ${ }^{2}$ and Z. Crnjak Orel ${ }^{2}$ \\ ${ }^{1}$ Institute "Ruđer Bošković”, P.O.Box 180, 10002 Zagreb, Croatia \\ ${ }^{2}$ National Institute of Chemistry, Hajdrihova 19, 1000 Ljubljana, Slovenia \\ Correspondence should be addressed to A. Turković, turkovic@irb.hr \\ Received 20 April 2010; Revised 17 August 2010; Accepted 22 September 2010 \\ Academic Editor: William W. Yu
}

Copyright (๑) 2011 A. Turković et al. This is an open access article distributed under the Creative Commons Attribution License, which permits unrestricted use, distribution, and reproduction in any medium, provided the original work is properly cited.

\begin{abstract}
We have investigated nanosized thin films of $\alpha-\mathrm{Fe}_{2} \mathrm{O}_{3}$ (hematite) and $\alpha-\mathrm{Fe}_{2} \mathrm{O}_{3}$ with addition of Li, by the impedance spectroscopy (IS), the Raman spectroscopy, scanning electron microscopy (SEM), and X-ray diffraction (XRD). Combining all of these methods, and earlier obtained thermally stimulated currents (TSC) on the same samples, the dependence of structural and electrical properties upon percentage of Li added into the matrix of these metal-oxide films was found. The comparison of IS, Raman, SEM, XRD, and TSC results reveals the increase of the size of nanoparticles upon inducing $1 \%$ of $\mathrm{Li}$ in $\mathrm{Fe}_{2} \mathrm{O}_{3}$ matrix followed by the decrease of the size of nanoparticles in the case of samples with $10 \% \mathrm{Li}$, as well as the decrease (increase) of conductivity, respectively. These changes are explained by the structural and morphological changes caused by the impact of $\mathrm{Li}^{+}$ions in the charge transfers. This material is suitable for application in the galvanic cell of second generation that could be used as solar-cells backup.
\end{abstract}

\section{Introduction}

Thin-films containing nanosized grains of $\mathrm{Fe}_{2} \mathrm{O}_{3}$ are widely used in research into mainly magnetic and electronic devices [1-5]. Their capacity for incorporating lithium ions is important in the construction of galvanic cells of second generation [6-17].

The one of newest and attractive application of $\mathrm{Fe}$ based batteries as high capacity LiFePO4 and LiFeYPO4 cells would be in electric vehicles [18]. Our intention is to construct charge-discharge $\mathrm{Fe}_{2} \mathrm{O}_{3}$-electrode battery with polymer electrolyte $[19,20]$. Further plan is to attach it to solar-cells [21-24] in order to preserve accumulated charge to use it in cloudy weather.

Films of iron oxide derived by the chemical deposition method route were investigated by the impedance spectroscopy (IS), Raman spectroscopy, SEM, and XRD in order to determine their electrical, structural, and morphological properties. Our goal was to establish the relation between electrical and the structural properties in nanostructured $\mathrm{Fe}_{2} \mathrm{O}_{3}$ and $\mathrm{Fe}_{2} \mathrm{O}_{3}$ : Li films on glass substrate.

IS was applied to measure the resistance of nanostructured $\mathrm{Fe}_{2} \mathrm{O}_{3}$ films with different contents of lithium. In our previous work [25], TSC spectra, often used in characterization of high resistive or semi-insulating (SI) materials [26, 27], were measured on the same samples, in order to investigate possible defects with deep levels in the forbidden energy gap and to see relation of it to the different percentages of Li.

By Raman and XRD measurements, we have determined, besides the hematite nature of our samples, that they are composed of the nanosized crystalline grains in the size range from $10 \mathrm{~nm}$ to $200 \mathrm{~nm}$, which was also proved by SEM investigation. It was also found that the variation of $\mathrm{Li}^{+}-$ ion content is related to the changes of the nanoparticles $(d<5 \mathrm{~nm})$ related to the acoustic phonons determined by the low frequency Raman measurements. We have also found samples' steadiness during the eight-month period.

\section{Experimental}

The samples were nanostructured $\mathrm{Fe}_{2} \mathrm{O}_{3}$ films deposited on the glass substrates and were prepared using chemical vapor deposition procedure shown on Figure 1. One percent water solution of $\mathrm{Fe}\left(\mathrm{NO}_{3}\right)_{3}$ with $\mathrm{LiNO}_{3}$ in 1 and 10 of at. \% regarding $\mathrm{Fe}$ and small quantity of $\mathrm{HNO}_{3}$ was sprayed onto substrate heated at $593 \mathrm{~K}$. The reaction is:

$$
2 \mathrm{Fe}\left(\mathrm{NO}_{3}\right)_{3} \longrightarrow \mathrm{Fe}_{2} \mathrm{O}_{3}+6 \mathrm{NO}_{2}+1.5 \mathrm{O}_{2}
$$


The home made apparatus for the preparation procedure was described previously [28].

The impedance measurements were performed using a homemade device consisting of an Impedance analyzer I100 and sample holder with built-in thermocouple copperconstantan with cold junction compensator OMEGA-CJ. Measurements were performed in vacuum of $10^{-2} \mathrm{mbar}$. PC using software developed in our laboratory recorded the impedance response. Impedance spectra were measured in the frequency range from $100 \mathrm{KHz}$ to $1 \mathrm{MHz}$. The samples (cubic-formed platelets consisting of $\mathrm{Fe}_{2} \mathrm{O}_{3}$ film on the glass substrate, with surface area of $100 \mathrm{~mm}^{2}$ and $2.5 \mathrm{~mm}$ thickness) mounted between two zinc electrodes were placed in a spring-contacted apparatus compressing the cell between zinc/teflon cylinders. The idea was to measure glass substrate without $\mathrm{Fe}_{2} \mathrm{O}_{3}$, and then with $\mathrm{Fe}_{2} \mathrm{O}_{3}$ films with different contents of Li. Measurements were consistent with model circuits [29], representing the sample/electrode systems as parallel sample resistance and capacitance in series with two impedances representing the electrode and sample characteristics.

TSC measurements were performed in the DL-4960 liquid nitrogen cryostat (Bio-Rad), using Keithley K-617 electrometer, under $+10 \mathrm{~V}$ applied bias voltage, where contacts show ohmic behavior. Samples were heated in the dark until $360 \mathrm{~K}$ (in order to empty all deep traps/levels) and then cooled in dark to $85 \mathrm{~K}$. After that, samples were illuminated with the white light during 600 seconds. Another fifty seconds samples were kept in the dark at $85 \mathrm{~K}$ and then temperature ramp with $\beta=0.4 \mathrm{~K} / \mathrm{s}$ was activated. During that, regular TSC spectra were recorded.

Raman spectra were recorded using Dilor Z24 Raman triple monochromator in a $45^{\circ}$ scattering configuration using $2 \mathrm{~W}$ of cylindrically focused $514.5 \mathrm{~nm}$ argon ion laser excitation. Micro-Raman spectra were recorded using Jobin Yvon T64000 in a backscattering configuration with objective LWD 50X of cylindrically focused $514.5 \mathrm{~nm}$ argon ion laser excitation.

The grain size, the crystallinity, and the morphology were observed using scanning field emission electron microscopy (SEM, Zeiss, Supra 35 VP).

The identification and classification of prepared samples were made by the X-ray diffraction using a D4 Endeavor, Bruker AXS.

\section{Results and Discussion}

The primary goal of impedance spectroscopy measurements was to determine the electrical conductivity of the $\mathrm{Fe}_{2} \mathrm{O}_{3}$ films and then $\mathrm{Fe}_{2} \mathrm{O}_{3}$ films with different contents of $\mathrm{Li}$. Conductivity results were collected using $\mathrm{Zn}$ electrodes with continuous heating in a noninterrupted range between the room temperature of $295 \mathrm{~K}$ and $305 \mathrm{~K}$. The conductivity values $\sigma$ were calculated using the following equation:

$$
\sigma=\frac{l}{S R}\left(\Omega \mathrm{cm}^{-1}\right)
$$

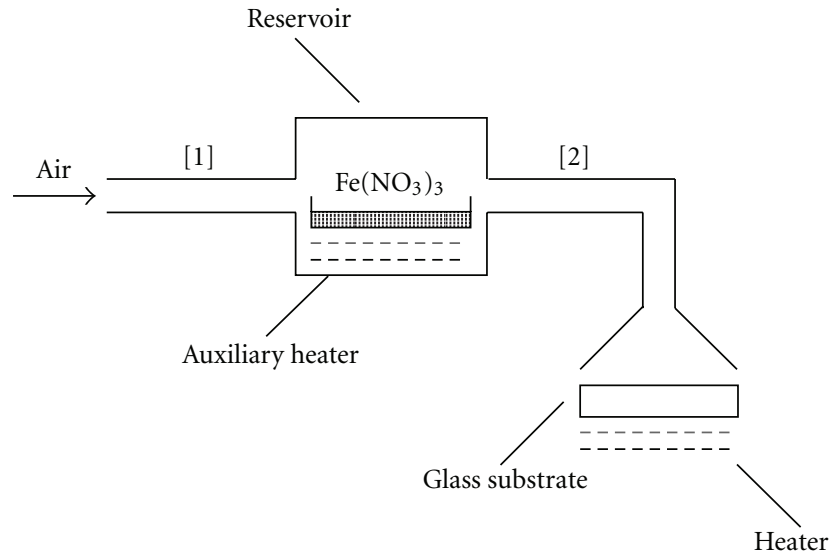

Figure 1: The Layout of the home made apparatus for CVD preparation of $\mathrm{Fe}_{2} \mathrm{O}_{3}$ thin films on glass substrate.

TABle 1: Obtained parameters for different $\mathrm{Fe}_{2} \mathrm{O}_{3}$ samples: measurement temperature in degrees of $K$, resistivity $R$ in $\mathrm{k} \Omega \mathrm{cm}$ obtained by IS, low-frequency Raman modes $n$ in $\mathrm{cm}^{-1}$, and their respective nanosizes $d$ in $\mathrm{nm}$ of $\mathrm{Fe}_{2} \mathrm{O}_{3}$ films on the glass substrate.

\begin{tabular}{lcccc}
\hline sample & $T / K$ & $R / \mathrm{k} \Omega \mathrm{cm}$ & $n / \mathrm{cm}^{-1}$ & $d / \mathrm{nm}$ \\
\hline $\mathrm{Fe}_{2} \mathrm{O}_{3}$ & 298 & 40 & 95 & 2.0 \\
$\mathrm{Fe}_{2} \mathrm{O}_{3}$ with $1 \% \mathrm{Li}$ & 298 & 250 & 50 & 3.9 \\
$\mathrm{Fe}_{2} \mathrm{O}_{3}$ with $10 \% \mathrm{Li}$ & 298 & 54 & 60 & 3.2 \\
\hline
\end{tabular}

where $l$ and $S$ are the thickness and the area of samples, respectively. $R$ is the sample resistance estimated from the ac admittance data, after fitting to the experimental curves.

Measurements with $\mathrm{Zn}$ electrodes were performed in impedance and admittance modes. Both measurements were performed because the bulk resistivity of the thin film of $\mathrm{Fe}_{2} \mathrm{O}_{3}, R_{b}$, was more accurately determined from admittance, while charge transfer resistance, $R_{c t}$, was determined from impedance measurements.

Figure 2 is showing an example of ac admittance data for the sample of $\mathrm{Fe}_{2} \mathrm{O}_{3}$ obtained at room temperature and equivalent circuits.

At low temperatures, the geometrical capacity was neglected. Its typical values are rather low $(\sim \mathrm{pF})$ deriving from a very high capacitive resistance in the $C_{g}$ branch compared with the parallel $R_{b}$. So, the influence of $C_{g}$ on the impedance on this parallel circuit can be neglected (Figure 2(b)).

We observed another arc at lower frequencies, which is attributed to a capacity between grain boundaries. By grains we assume crystallites divided by double layers between them. As $R_{g b}$ was much bigger than $R_{b}$, its influence to the impedance circuit could be neglected so that only $C_{g b}$ was left.

Figure 3 shows the conductivity plot in the range from 295 to $305 \mathrm{~K}$ for $\mathrm{Fe}_{2} \mathrm{O}_{3}$ and $\mathrm{Fe}_{2} \mathrm{O}_{3}$ : Li samples. Resistivities $(R)$ obtained from admittance measurements at room temperature are shown in the second column of Table 1. 


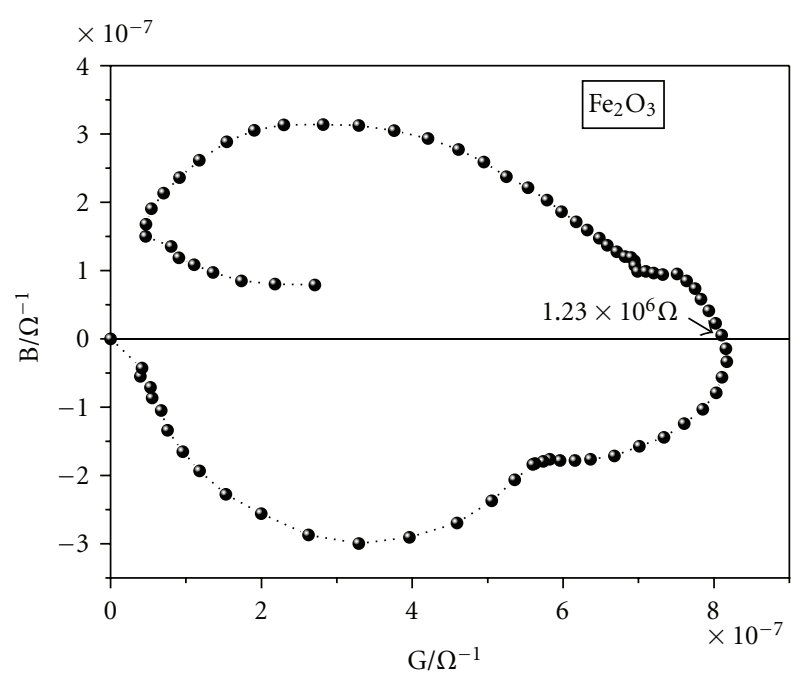

(a)

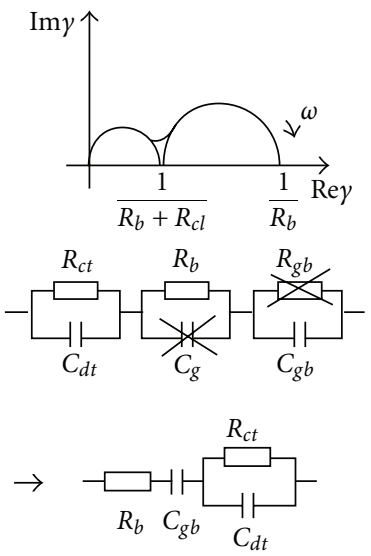

(b)

FIgURE 2: (a) Admittance spectra $\mathrm{Fe}_{2} \mathrm{O}_{3}$ thin film measured at room temperature and (b) equivalent circuits and schematic admittance plot for $\mathrm{Zn}$ electrodes.

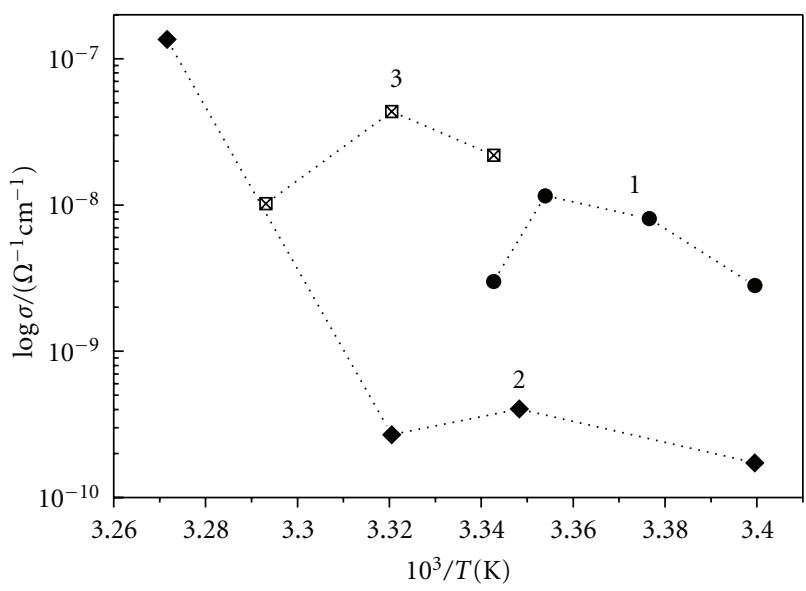

Figure 3: $\log \sigma$ versus $1000 / T$ for $\mathrm{Fe}_{2} \mathrm{O}_{3}(1), \mathrm{Fe}_{2} \mathrm{O}_{3}$ with $1 \%(2)$ and $\mathrm{Fe}_{2} \mathrm{O}_{3}$ with $10 \%$ of $\mathrm{Li}(3)$ measured with $\mathrm{Zn}$ electrodes.

Figure 4. shows TSC spectra of three $\mathrm{Fe}_{2} \mathrm{O}_{3}$ samples with different $\mathrm{Li}$ content, e.a. pure $\mathrm{Fe}_{2} \mathrm{O}_{3}(0 \% \mathrm{Li})$, with $1 \%$ and finally with $10 \%$ of Li, respectively. This figure, showing (a) low- and (b) high-temperature regions, illustrates changes in the defect concentrations related to the different $\mathrm{Li}$ contents. Low-temperature TSC spectra are characterized by the negative peak around $155 \mathrm{~K}$, related to the deep trap $T_{2}$ (with activation energy, $E_{a}=0.28 \mathrm{eV}$ ) and calculated by equation [25]:

$$
E_{a}=k T_{m} \ln \left(\frac{T_{m}^{4}}{\beta}\right)
$$

where $\mathrm{k}$ is the Boltzman's constant, $T_{m}$ is temperature of TSC peak maximum (in $\mathrm{K}$ ), and $\beta$ is heating rate in $\mathrm{K} / \mathrm{s}$. It was observed in $\mathrm{Fe}_{2} \mathrm{O}_{3}$ Li-free samples and in TSC of $\mathrm{Fe}_{2} \mathrm{O}_{3}$ with $1 \% \mathrm{Li}$. According to the literature $[30,31]$, we assign our
TABLE 2: Main parameters of deep traps found in $\mathrm{Fe}_{2} \mathrm{O}_{3}$ samples.

\begin{tabular}{lccccc}
\hline Trap & $T_{1}$ & $T_{2}$ & $T_{3}$ & $T_{4}$ & $T_{5}$ \\
\hline$E_{a}(\mathrm{eV})$ & 0.18 & 0.28 & 0.36 & 0.64 & 0.68 \\
$T_{m}(\mathrm{~K})$ & 107 & 155 & 188 & 308 & 327 \\
\hline
\end{tabular}

peak $T_{2}$ to the hole trap. Two neighboring peaks, $T_{1}$ (with $T_{m}=107 \mathrm{~K}$ and $E_{a}=0.18 \mathrm{eV}$ ) as well as $T_{3}$ (at $188 \mathrm{~K}$, $0.36 \mathrm{eV}$ ) should correspond to electron traps. TSC spectrum of the sample with $10 \% \mathrm{Li}$ shows the increase of $T_{1}$ and $T_{3}$ concentrations, which "screened" negative peak $T_{2}$. It can be explained by abundant release of oppositely charged carrierselectrons from $T_{1}$ and $T_{3}$ traps and/or by the decrease of the holes traps concentration caused by the structural changes after $\mathrm{Li}$ entered into the structure. It should be noticed that doping with $1 \%$ of $\mathrm{Li}$ causes increase in $T_{2}$ hole trap concentration, while further doping (10\%) increases $T_{1}$ and $T_{3}$ peaks. The same observation can be applied for TSC peaks in high-T region. Namely, peaks $T_{4}$ (at $308 \mathrm{~K}, 0.64 \mathrm{eV}$ ) and $T_{5}(327 \mathrm{~K}, 0.68 \mathrm{eV})$ decrease in samples with $1 \% \mathrm{Li}$ and enormously increase in samples with $10 \%$ Li content. Main deep trap parameters are presented in Table 2.

In this work, we have determined nanosized values for the acoustic phonons in $\mathrm{Fe}_{2} \mathrm{O}_{3}$ by using the method of lowfrequency Raman scattering that had been tested on different powder systems in our previous work [32]. Generally, this method is based on the work of Duval et al. [33], who showed that the maximum of the low-frequency mode of a free particles, $n$, corresponds to the angular momentum $l=0$ and it is given by

$$
n=0.7\left(v_{l} /(d \cdot c)\right)
$$

where $c$ is the velocity of light in vacuum, $v_{l}$ is the longitudinal velocity of sound, and $d$ is particle diameter. In calculations, we have used $v_{l}=8300 \mathrm{~m} / \mathrm{s}$ of a- $\mathrm{Fe}_{2} \mathrm{O}_{3}$ [34]. 


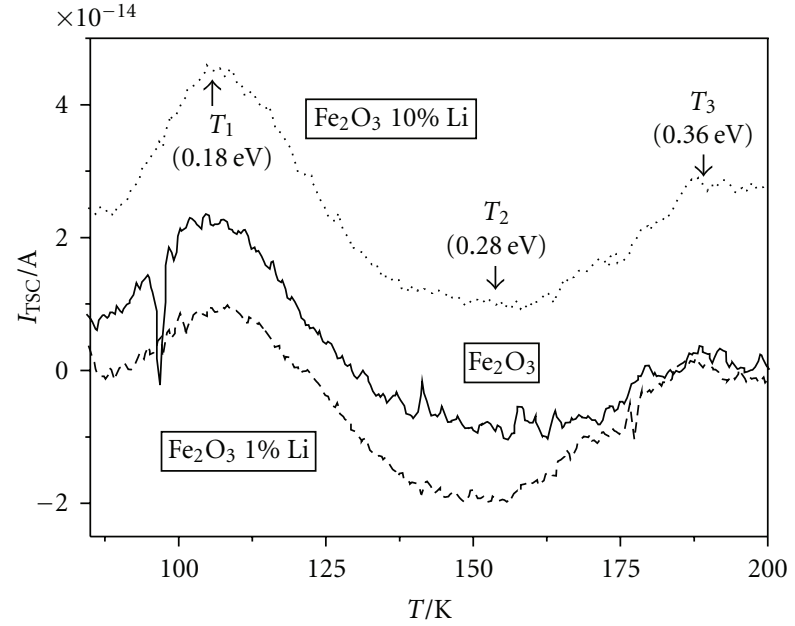

(a)

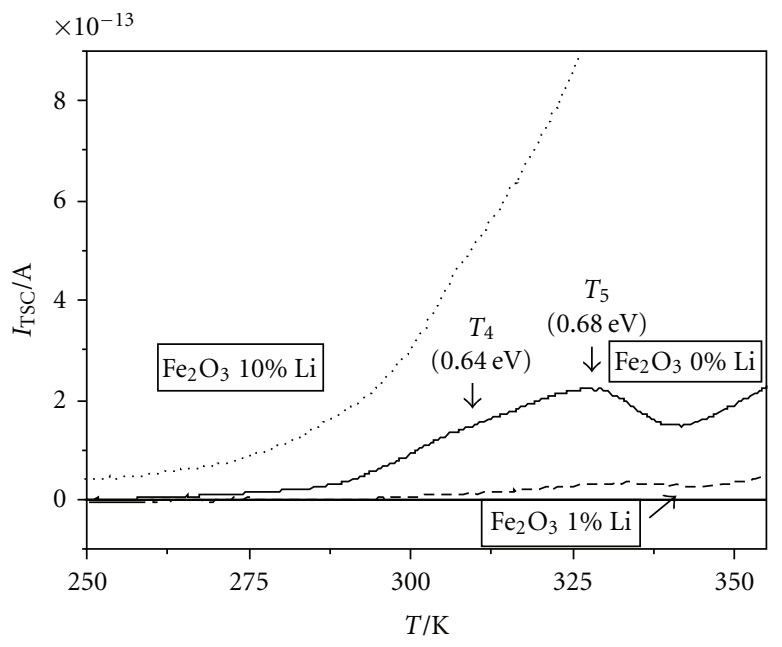

(b)

FIGURE 4: TSC spectra of (a) low- and (b) high-temperature region of three samples with different $\mathrm{Li}$ content, e.a. $\mathrm{Fe}_{2} \mathrm{O}_{3}$ ( $\mathrm{Li}$ free), $\mathrm{Fe}_{2} \mathrm{O}_{3}$ with $1 \%$ and $\mathrm{Fe}_{2} \mathrm{O}_{3}$ with $10 \%$ of Li.

The results of calculations are presented in Table 1. Raman spectra, measured at room temperature and used in $\mathrm{Fe}_{2} \mathrm{O}_{3}$ nanosizes determination, are shown at Figure 5. Average nanosizes in sample with $1 \%$ of $\mathrm{Li}$ increased regarding to the original $\mathrm{Li}$ free sample from $2.0 \mathrm{~nm}$ to $3.9 \mathrm{~nm}$. After addition of $10 \%$ of $\mathrm{Li}$, nanosizes were reduced to $3.2 \mathrm{~nm}$.

We have performed assignation of Raman lines according to the literature [35-38] as hematite and it is shown in Table 3. Hematite, $\alpha-\mathrm{Fe}_{2} \mathrm{O}_{3}$ with corundum structure belongs to the $D_{3 d}^{6}$ crystal space group, which gives seven characteristic phonon lines $2 A_{1 g}+5 E_{g}$ that are Ramanactive fundamentals. Additional Raman experiments were performed after period of 8 months showing stability of hematite phase. Shift of the Raman lines towards higher frequencies upon insertion of $\mathrm{Li}^{+}$-ions into the structure is also showing nanostructured $[39,40]$ nature of the films.

In further discussion, we will try to correlate the results of three types of measurements (IS, TSC [25], and Raman) in order to gain insight in microscopic resistivity increase upon addition of Li.

Charge transport in simple $3 \mathrm{~d}$ oxide crystals such as $\alpha$ $\mathrm{Fe}_{2} \mathrm{O}_{3}$ can be described in terms of hopping and narrowband conduction by polarons [41]. The electron transition in $\alpha-\mathrm{Fe}_{2} \mathrm{O}_{3}$ usually occurs between the partially filled $3 \mathrm{~d}$ orbital and the nearly empty sp orbital of $\mathrm{O}$. In a narrow band semiconductors like $\alpha-\mathrm{Fe}_{2} \mathrm{O}_{3}$, disorder may produce localized states in the whole band. The disorder potential between adjacent states is [41]

$$
W_{D} \geq 6(2 J z)
$$

where $J$ is the overlap integral between $3 \mathrm{~d}$ orbitals and $z$ the number of nearest neighbours. In this case, conduction takes place by phonon-assisted hopping of electrons.

The polaron theory that is in detail presented in [41] is one of the possible approaches to interpret our data. Here we introduce view of nanosized acoustic phonons in Raman spectra as quasiparticles, when coupled to the electron, that is, nanoparticle. Low-frequency Raman showed that adding of $1 \% \mathrm{Li}$ induced significant changes in the nanoparticle size $(2 \mathrm{~nm} \rightarrow 3.9 \mathrm{~nm})$, which is the increase of $95 \%$, and accordingly in the conduction mechanism. $\mathrm{Li}^{+}$ions affected holes traps as determined by TSC [25] by increasing their concentration, while electron traps concentration decreased. Activation energies of electrons' and holes' traps $T_{1}-$ $T_{5}$ remained almost the same $(0.18,0.28,0.36,0.64$, and $0.68 \mathrm{eV})$, respectively [25]. One possible explanation is that $\mathrm{Li}^{+}$ions combined with related defects in the unit cell causing decrease of overlap integrals and accordingly decrease in the disorder potential $W_{D}$. This induced tensions in the structure that resulted by the nanoparticle enlargement and accordingly its mobility decreases. Increase in resistivity for more than six times was observed (Table 1). The situation is quite different in samples with $10 \% \mathrm{Li}$ : nanoparticle size decreased from $3.9 \mathrm{~nm}$ to $3.2 \mathrm{~nm}$ and resistivity simultaneously decreased almost to the value of the referent Li free sample. The increase of the conductivity is due to structural disorder created by $\mathrm{Li}^{+}$ions, which are having ten times greater concentration than in the sample with $1 \% \mathrm{Li}$. In such disordered structure, disorder potential can vanish and nanoparticle can easily move through the sample. The mechanism of hopping electrons can also occur and add to the conductivity increase. The same observation can be applied for TSC peaks in high- $T$ region, namely, peaks $T_{4}$ (at $308 \mathrm{~K}$, $0.64 \mathrm{eV})$ and $T_{5}(327 \mathrm{~K}, 0.68 \mathrm{eV})$ decrease in samples with $1 \% \mathrm{Li}$ and enormously increase in samples with $10 \% \mathrm{Li}$ [25]. These two peaks represent deep traps and as they decrease upon addition of $1 \%$ of $\mathrm{Li}$, the conductivity also decreases, which is in agreement with IS measurements (Table 1). Further increase of $\mathrm{Li}$ content to $10 \%$ increases concentrations of these traps and conductivity increases, due to enlarged release of electrons from traps, which is also in accordance with IS results. The increase in deep traps concentrations indicates that samples with $10 \% \mathrm{Li}$ are amorphous.

Scanning field emission electron microscopy and XRD measurements were performed in order to check the grain size, the crystallinity, and the morphology, revealed by other methods. 
TABLE 3: Raman wave numbers and assignments of the hematite films prior and after addition of $\mathrm{Li}^{+}$ions.

\begin{tabular}{|c|c|c|c|c|c|c|}
\hline \multirow{3}{*}{ Assignation } & \multicolumn{6}{|c|}{ Raman shift $/ \mathrm{cm}^{-1}$} \\
\hline & \multicolumn{3}{|c|}{1} & \multicolumn{3}{|c|}{2} \\
\hline & $\mathrm{Fe}_{2} \mathrm{O}_{3}$ & $\mathrm{Fe}_{2} \mathrm{O}_{3}+1 \% \mathrm{Li}$ & $\mathrm{Fe}_{2} \mathrm{O}_{3}+10 \% \mathrm{Li}$ & $\mathrm{Fe}_{2} \mathrm{O}_{3}$ & $\mathrm{Fe}_{2} \mathrm{O}_{3}+1 \% \mathrm{Li}$ & $\mathrm{Fe}_{2} \mathrm{O}_{3}+10 \% \mathrm{~L}$ \\
\hline & $78 \mathrm{w}$ & $56 \mathrm{sh}$ & $69 \mathrm{vw}$ & & & \\
\hline & $99 \mathrm{sh}$ & & & & & \\
\hline $\operatorname{Alg}(1)$ & $213 \mathrm{vs}$ & $221 \mathrm{w}$ & $221 \mathrm{~m}$ & $223 \mathrm{~s}$ & $223 \mathrm{sh}$ & $219 \mathrm{vw}$ \\
\hline \multirow[t]{2}{*}{$\operatorname{Eg}(1)$} & & & & $241 \mathrm{sh}$ & $245 \mathrm{w}$ & $241 \mathrm{vw}$ \\
\hline & & & & & $267 \mathrm{sh}$ & \\
\hline $\operatorname{Eg}(1)$ & 282 vs & 286 vs & $284 \mathrm{~m}$ & 290 vs & $297 \mathrm{~m}$ & $296 \mathrm{~m}$ \\
\hline $\operatorname{Eg}(1)$ & $395 \mathrm{w}$ & 402 vs & $393 \mathrm{~s}$ & $404 \mathrm{~s}$ & 407 vs & $407 \mathrm{~s}$ \\
\hline $\operatorname{Alg}(2)$ & & $488 \mathrm{w}$ & $490 \mathrm{w}$ & $490 \mathrm{vw}$ & & \\
\hline $\operatorname{Eg}(1)$ & $586 \mathrm{w}$ & $608 \mathrm{w}$ & $600 \mathrm{w}$ & $608 \mathrm{w}$ & $609 \mathrm{w}$ & $608 \mathrm{w}$ \\
\hline
\end{tabular}

1: First measurement, 2: Second measurement after 8 months: vs: very strong, s: strong, m: medium, sh: shoulder, w: weak, vw: very weak.

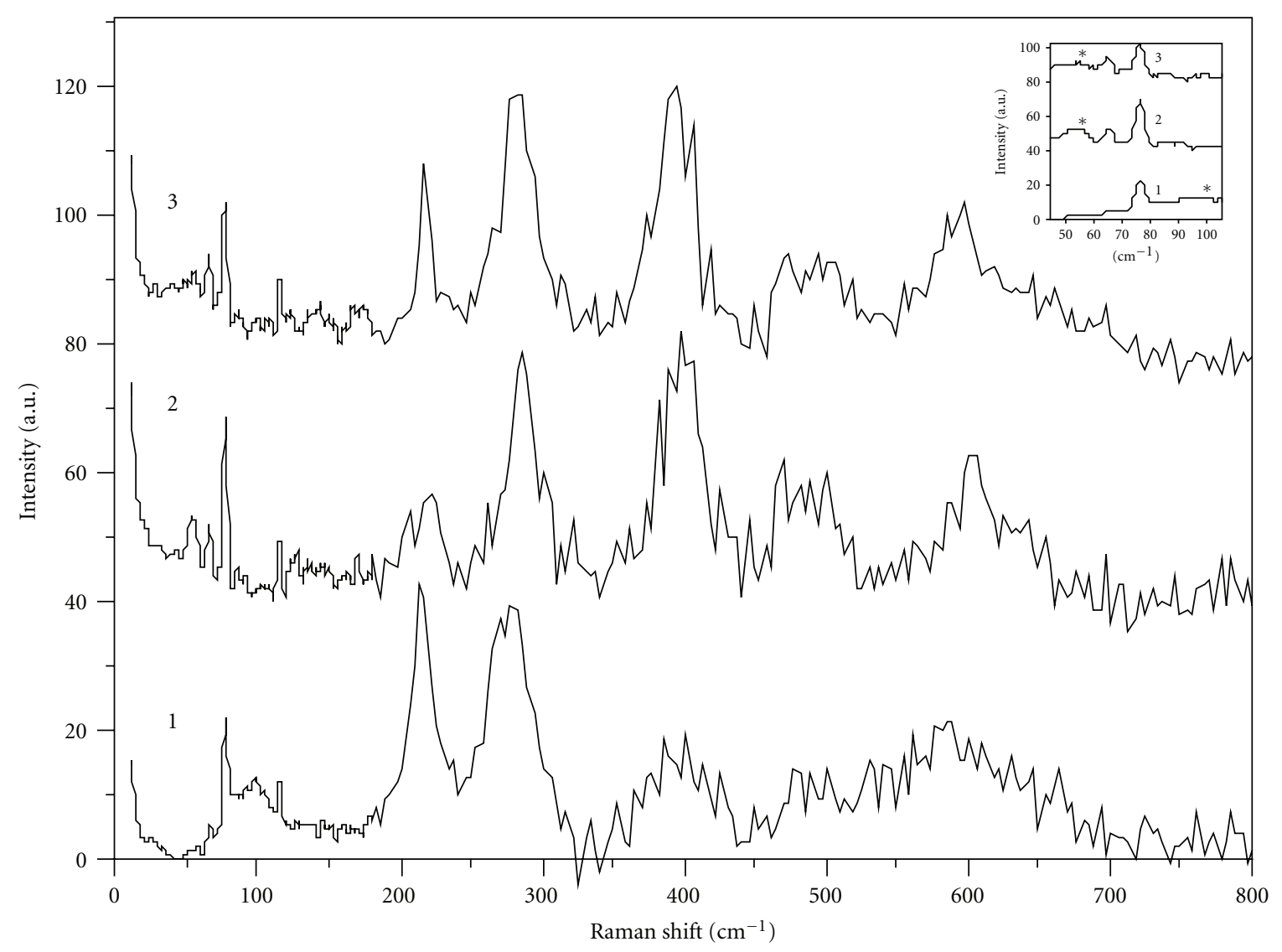

Figure 5: Raman spectra of $\mathrm{Li}$ free $\mathrm{Fe}_{2} \mathrm{O}_{3}(1), \mathrm{Fe}_{2} \mathrm{O}_{3}$ with $1 \%(2)$, and $\mathrm{Fe}_{2} \mathrm{O}_{3}$ with $10 \%$ of $\mathrm{Li}$ (3). Inset shows low-frequency region of the same spectra pointing out low frequency modes revealing nanosizes.

SEM photographs of $\alpha-\mathrm{Fe}_{2} \mathrm{O}_{3}$ and of the same material with added Li ions are shown on Figure 6. It is clearly visible on lower magnification that sample (a) shows much more homogeneous surface than the samples (c) and (e). The crystallinity is changed and films (c) and (e) became partly and completely amorphous, respectively. The surface of sample (e) shows good homogeneity and on higher magnification some nanoagglomerated grains are visible. Figures 6(b), 6(d), and 6(f) present SEM photographs of the same films after 8 months, demonstrating no significant difference upon earlier results.

On higher magnification in Figure 7, it is shown that film $\mathrm{Fe}_{2} \mathrm{O}_{3}$ is formed from nanograins in the radius, $R$, range from $75 \mathrm{~nm}$ to $240 \mathrm{~nm}$. The maximum for grain size distribution 


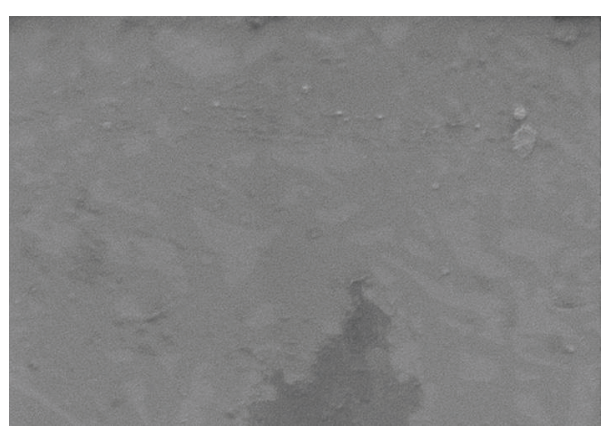

(a)

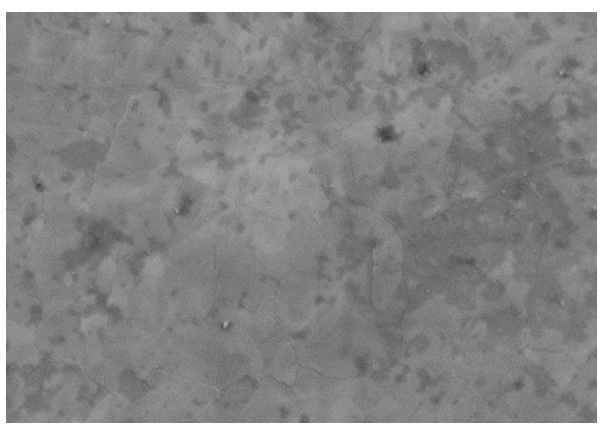

(c)

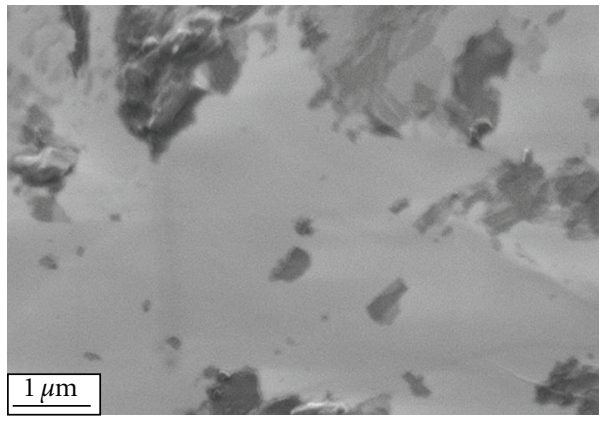

(e)

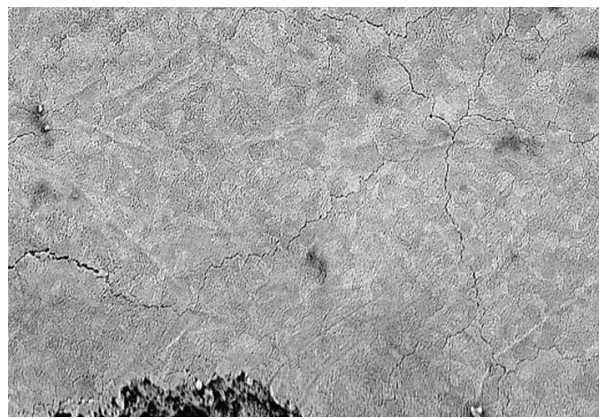

(b)

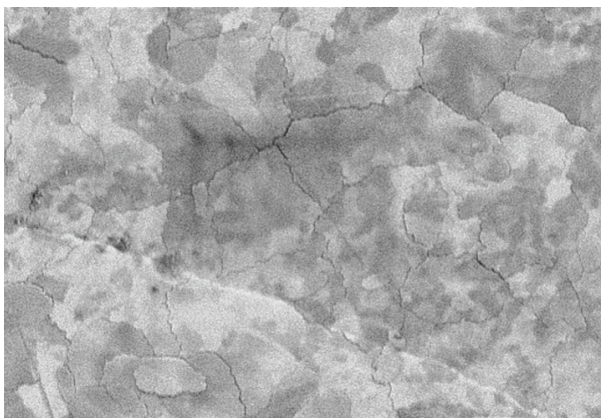

(d)

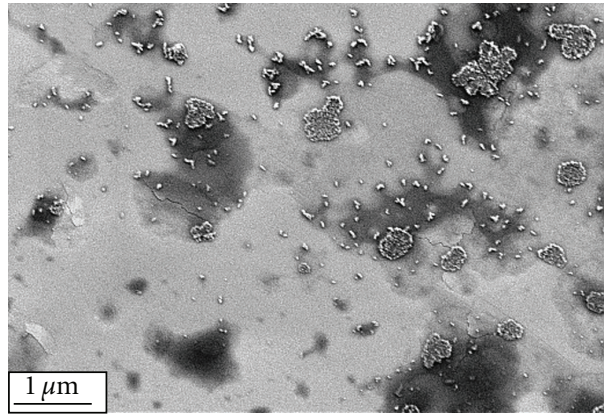

(f)

Figure 6: SEM photographs Li free $\mathrm{Fe}_{2} \mathrm{O}_{3}$ (a), $\mathrm{Fe}_{2} \mathrm{O}_{3}$ with $1 \%$ (c) and $\mathrm{Fe}_{2} \mathrm{O}_{3}$ with $10 \%$ of $\mathrm{Li}(\mathrm{e})$, and the same films after 8 months (b), (d), and (f), respectively.

is at $R=120 \mathrm{~nm}$ as fitted to Lorentian shape. It is confirmed that the grains are crystalline as shown on XRD spectra shown on Figure 8. The tensions in the crystalline structure are seen as cracks in Figure 7.

The results of the XRD measurements of the samples prepared as films on the glass substrate are presented on Figure 8. The prepared film on Figure 8(a) showed the characteristic diffractogram of hematite structure (reference code 01-079-1741, mineral name: Hematite, synthetic, ICSD name: Iron Oxide).

We have calculated grain sizes in $\mathrm{Fe}_{2} \mathrm{O}_{3}$ by using DebyeScherrer formula:

$$
D=\frac{0.9 \cdot \lambda}{\beta \cos \theta}
$$

where $D$ is diameter of grain, $\lambda$ is the wavelength of the $\mathrm{X}$ ray beam, $\beta$ is the width at the half height of the particular line in radians, and $\cos \theta$ is the position of the peak in $2 \theta$ scale. $D$ values were obtained in the range from to $20 \mathrm{~nm}$ to $110 \mathrm{~nm}$, which is in agreement with the nanometre range of grain sizes observed on SEM photograph shown in Figure 7.

At Figure 8(b), only one small intensity peak at $39.295^{\circ}$ with $D=27 \mathrm{~nm}$ is shown. The recordings were with the same intensity (see $y$-axes) as in Figure 8(a). Figure 8(c) is not showing any crystalline lines. Figure 8 clearly shows amorphization of the sample upon addition of $\mathrm{Li}^{+}$ions, from pure crystalline hematite (a), through amorphous phase with $1 \% \mathrm{Li}$ (b) and to completely amorphous phase with $10 \% \mathrm{Li}$ (c).

\section{Conclusion}

As a conclusion, the present study showed that IS, Raman spectroscopy, SEM, and XRD could be applied for grain 


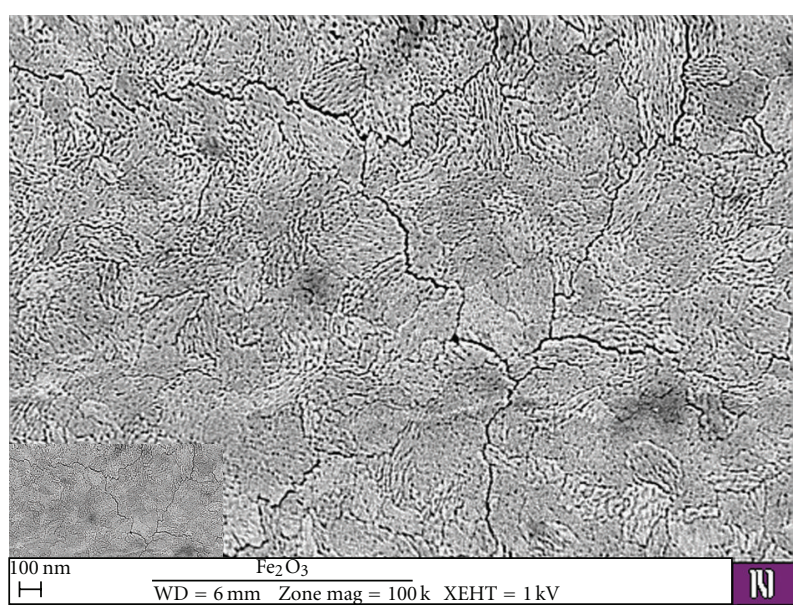

Figure 7: SEM photograph Li free $\mathrm{Fe}_{2} \mathrm{O}_{3}$ (a), with higher magnification of $100.00 \mathrm{~K}$.

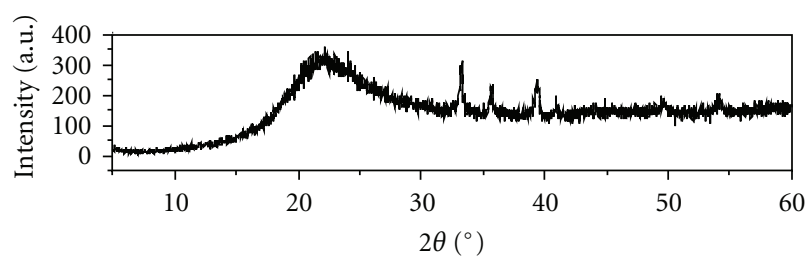

(a)

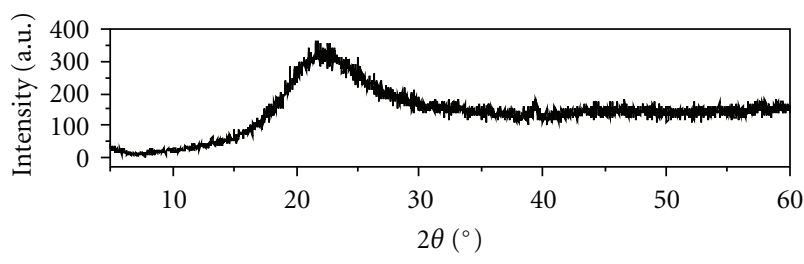

(b)

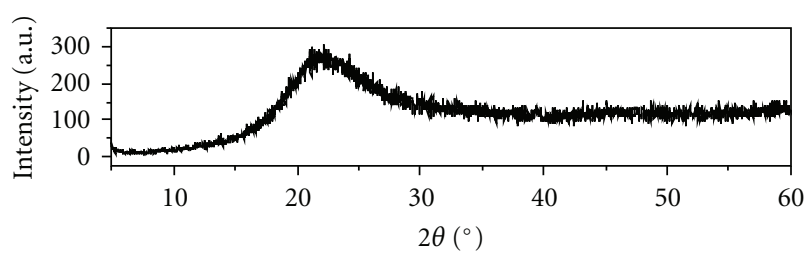

(c)

FIGURE 8: XRD spectra of $\mathrm{Fe}_{2} \mathrm{O}_{3}$ (a), $\mathrm{Fe}_{2} \mathrm{O}_{3}$ with $1 \%$ (b), and $\mathrm{Fe}_{2} \mathrm{O}_{3}$ with $10 \%$ of $\operatorname{Li}(\mathrm{c})$.

size and conductivity determination in nanosized films of $\mathrm{Fe}_{2} \mathrm{O}_{3}$ and $\mathrm{Fe}_{2} \mathrm{O}_{3}$ : Li on glass substrate. The results obtained with IS, Raman spectroscopy and previously, with TSC analysis [25], together with XRD and SEM give complementary data to build a model of the charge transport in these nanostructured films. IS revealed trends in conductivity changes, while TSC gave insight in deep traps concentration changes related to the increase of $\mathrm{Li}$ percentage in $\mathrm{Fe}_{2} \mathrm{O}_{3}$. By the low-frequency Raman spectroscopy, it was possible to follow changes of the nanoparticles (which are acustic phonons coupled to electrons with the nanosize diameter range $d<$ $5 \mathrm{~nm}$ ), during the structural changes induced by the introduction of $\mathrm{Li}$ into the $\mathrm{Fe}_{2} \mathrm{O}_{3}$. It was observed that nanoparticles sizes are increasing with addition of $\mathrm{Li}$ to the films, and a little bit decreasing with further increase of Li content. Also, Raman spectroscopy showed that we were dealing with nanostructured $\alpha-\mathrm{Fe}_{2} \mathrm{O}_{3}$ (hematite) films. Samples also showed steadiness, during rest period of eight months. XRD measurements additionally proved that samples are $\alpha-\mathrm{Fe}_{2} \mathrm{O}_{3}$, hematite phase of iron oxide. SEM patterns, as well as Raman and $\mathrm{XRD}$, showed that the addition of $\mathrm{Li}^{+}$ions have changed nanostructure of the samples from the crystalline grains in the diameter range $D>20 \mathrm{~nm}$ to the amorphous phase.

Here we point out the distinction between the two terms, nanoparticles and nanograins, used in this paper, as they are describing noncrystalline and crystallnine forms, respectively. Nanoparticles could be possibly seen as seeds for the amorphization process during the increase of $\mathrm{Li}$ percentage in our samples.

This particular morphology is suitable for application in an advanced electrochemical cell concept, which could be used as charge storage for solar cells.

\section{Acknowledgments}

The authors thank the Croatian and the Slovenian Ministries of Science and Technology for financially supporting this work.

\section{References}

[1] J. Zhu and K. J. Tseng, "Reducing dielectric losses in MnZn ferrites by adding $\mathrm{TiO}_{2}$ and $\mathrm{MoO}_{3}$," IEEE Transactions on Magnetics, vol. 40, no. 5, pp. 3339-3345, 2004.

[2] C. N. R. Rao, G. U. Kulkarni, P. J. Thomas, V. V. Agrawal, U. K. Gautam, and M. Ghosh, "Nanocrystals of metals, semiconductors and oxides: novel synthesis and applications," Current Science, vol. 85, no. 7, pp. 1041-1045, 2003.

[3] L. L. Casas, A. Roig, E. Rodríguez, E. Molins, J. Tejada, and J. Sort, "Silica aerogel-iron oxide nanocomposites: structural and magnetic properties," Journal of Non-Crystalline Solids, vol. 285, no. 1-3, pp. 37-43, 2001.

[4] T. Mizushima, A. Makino, F. Kaneko, and S. Kobayashi, "Soft magnetic properties of single crystalline Mn- Zn ferrites containing $\mathrm{Er}_{2} \mathrm{O}_{3}$," Materials Transactions, JIM, vol. 32, no. 12, pp. 1177-1179, 1991.

[5] Z. Y. Ling, M. R. Xiong, and Q. Q. Zhang, "Effects of iron deficiency on magnetic properties of $\left(\mathrm{Ni}_{0.76} \mathrm{Zn}_{0.24}\right) \mathrm{O}\left(\mathrm{Fe}_{2} \mathrm{O}_{3}\right)_{0.575}$ ferrite," Journal of Magnetism and Magnetic Materials, vol. 219, no. 1, pp. 9-14, 2000.

[6] Y. Zhang, X.-P. Gao, H. Hu et al., "Electrochemical performance of carbon nanotubes filled with $\mathrm{Fe}_{2} \mathrm{O}_{3}$ as anode materials for Li-ion batteries," Chinese Journal of Inorganic Chemistry, vol. 20, no. 9, pp. 1013-1017, 2004.

[7] T. Grygar, P. Bezdička, D. Hradil, and L. Pikna, "Electrochemical analysis of metal oxides," Solid State Phenomena, vol. 90-91, pp. 45-50, 2003.

[8] T. Matsumura, N. Sonoyama, R. Kanno, and M. Takano, "Lithiation mechanism of new electrode material for lithium ion cells- the $\alpha-\mathrm{Fe}_{2} \mathrm{O}_{3}-\mathrm{SnO}_{2}$ binary system," Solid State Ionics, vol. 158, no. 3-4, pp. 253-260, 2003. 
[9] S. Komaba, K. Suzuki, and N. Kumagai, "Synthesis of nanocrystalline $\mathrm{Fe}_{2} \mathrm{O}_{3}$ for lithium secondary battery cathode," Electrochemistry, vol. 70, no. 7, pp. 506-510, 2002.

[10] C.-W. Kwon, A. Poquet, S. Mornet, G. Campet, J. Portier, and J.-H. Choy, "A new polypyrrole/maghemite hybrid as a lithium insertion electrode," Electrochemistry Communications, vol. 4, no. 2, pp. 197-200, 2002.

[11] W. Wong-Ng, R. S. Roth, T. A. Vanderah, and H. F. McMurdie, "Phase equilibria and crystallography of ceramic oxides," Journal of Research of the National Institute of Standards and Technology, vol. 106, no. 6, pp. 1097-1134, 2001.

[12] N. Cui and J. L. Luo, "Effects of oxide additions on electrochemical hydriding and dehydriding behavior of $\mathrm{Mg}_{2} \mathrm{Ni}-$ type hydrogen storage alloy electrode in $6 \mathrm{M} \mathrm{KOH}$ solution," Electrochimica Acta, vol. 44, no. 5, pp. 711-720, 1998.

[13] S. Ito, K. Ui, N. Koura, and K. Akashi, "Lithium secondary battery using potassium- $\beta$-ferrite as a new cathode active material," Solid State Ionics, vol. 113-115, pp. 17-21, 1998.

[14] J. Sarradin, M. Ribes, A. Guessous, and K. Elkacemi, "Study of $\mathrm{Fe}_{2} \mathrm{O}_{3}$-based thin film electrodes for lithium-ion batteries," Solid State Ionics, vol. 112, no. 1-2, pp. 35-40, 1998.

[15] A. M. Mastral, M. J. Perez-Surio, and J. M. Palacios, "Thermal and chemical modifications on a low rank coal by iron addition in swept fixed bed hydropyrolysis," Fuel, vol. 77, no. 6, pp. 585-590, 1998.

[16] S. Ito, K. Ui, N. Hoshi, H. Kurosawa, N. Koura, and K. Akashi, " $\mathrm{K}^{+}-\beta$-ferrite as a new cathode active material for lithium secondary battery," vol. 7, no. C1, pp. C1-161-C1-162.

[17] A. Guerrero, A. Romero, R. D. Morales, and F. Chavez, "Thermodynamic analysis of the soda ash smelting of lead acid battery residue in a rotary furnace," Canadian Metallurgical Quarterly, vol. 36, no. 2, pp. 121-130, 1997.

[18] GWL group, Europe; http://www.yttrium-power.com/.

[19] A. Turković, A. Drašner, D. Šokčević, M. Ritala, T. Asikainen, and M. Leskelä, "Comparison between CVD and ALE produced $\mathrm{TiO}_{2}$ cathodes in $\mathrm{Zn} /(\mathrm{PEO})_{4} \mathrm{ZnCl}_{2} / \mathrm{TiO}_{2}, \mathrm{SnO}_{2}$ or ITO galvanic cells," Journal de Physique IV, vol. 5, no. C5, pp. 11331139, 1995.

[20] A. Turković and Z. Crnjak Orel, "Electrical and optical properties of $\mathrm{zn} /(\mathrm{PEO})_{4} \mathrm{ZnCl}_{2} /\left[\mathrm{CeO}_{2}\right.$ or $\left.\mathrm{CeO}_{2}-\mathrm{SnO}_{2}(17 \%)\right]$; ITO thin film galvanic cells," Solid State Ionics, vol. 89, no. 3-4, pp. 255-261, 1996.

[21] A. Turkovic, H. Zorc, D. Kontrec, and V. Vranesa, "Comparative study of organo-metallic dyes and fullerenes in dyesensitized $\mathrm{TiO}_{2}$ solar cells," Strojarstvo, vol. 38, no. 6, p. 257, 1996.

[22] A. Turković and Z. C. Orel, "Dye-sensitized solar cell with $\mathrm{CeO}_{2}$ and mixed $\mathrm{CeO}_{2} / \mathrm{SnO}_{2}$ photoanodes," Solar Energy Materials and Solar Cells, vol. 45, no. 3, pp. 275-281, 1997.

[23] Y. Wang, T. Yu, X. Chen et al., "Enhancement of photoelectric conversion properties of $\mathrm{SrTiO}_{3} / \alpha-\mathrm{Fe}_{2} \mathrm{O}_{3}$ heterojunction photoanode," Journal of Physics D, vol. 40, no. 13, pp. 3925-3930, 2007.

[24] M. B. Sahana, C. Sudakar, G. Setzler et al., "Bandgap engineering by tuning particle size and crystallinity of $\mathrm{SnO}_{2}$ $\mathrm{Fe}_{2} \mathrm{O}_{3}$ nanocrystalline composite thin films," Applied Physics Letters, vol. 93, no. 23, Article ID 231909, 2008.

[25] A. Turković, M. Pavlović, M. Ivanda, M. Gaberšček, and Z. C. Orel, "Influence of intercalated lithium on structural and electrical properties of $\mathrm{V}_{2} \mathrm{O}_{5}$, mixed $\mathrm{V} / \mathrm{Ce}$ oxide, and $\mathrm{Fe}_{2} \mathrm{O}_{3}$," Journal of the Electrochemical Society, vol. 153, no. 1, pp. A122A126, 2006.
[26] Z. Fang, L. Shan, T. E. Schlesinger, and A. G. Milnes, "Study of defects in LEC-grown undoped SI-GaAs by thermally stimulated current spectroscopy," Materials Science and Engineering B, vol. 5, no. 3, pp. 397-408, 1990.

[27] M. Pavlović, U. V. Desnica, and J. Gladić, "Complete set of deep traps in semi-insulating GaAs," Journal of Applied Physics, vol. 88 , no. 8 , pp. 4563-4570, 2000.

[28] A. Turković, D. Šokcević, T. Valla, M. Milun, and J. Rukavina, "Thermal stability of CV deposited $\mathrm{TiO}_{2}$ Thin Films. XPS and AES characterisation," Fizika A, vol. 2, pp. 23-34, 1993.

[29] A. Turković and Z. Crnjak Orel, "Electrical and optical properties of $\mathrm{zn} /(\mathrm{PEO})_{4} \mathrm{ZnCl}_{2} /\left[\mathrm{CeO}_{2}\right.$ or $\left.\mathrm{CeO}_{2}-\mathrm{SnO}_{2}(17 \%)\right]$; ITO thin film galvanic cells," Solid State Ionics, vol. 89, no. 3-4, pp. 255-261, 1996.

[30] S. Singh, "TSC curves in $(\mathrm{ZnO}-\mathrm{MgO}): \mathrm{Fe}, \mathrm{O}$ photoconductor: existence of negative and oscillatory characters," Journal of Materials Science, vol. 8, no. 6, pp. 848-850, 1973.

[31] C.-H. Lee, G.-N. Jeon, S.-C. Yu, and S.-Y. Ko, "Simultaneous measurement of thermally stimulated luminescence and thermally stimulated current of ZnSe single crystal," Journal of Physics D, vol. 28, no. 7, pp. 1951-1957, 1995.

[32] M. Ivanda, A. M. Tonejc, I. Djerdj et al., "Determination of nanosized particles distribution by low freqyency Raman scattering: comparison to electron microscopy," in Lecture Notes in Physics: Nanoscale Spectroscopy and Its Applications to Semiconductor Research, Y. Watanabe, S. Heun, G. Salviati, and N. Yamamoto, Eds., pp. 16-27, Springer, New York, NY, USA, 2002.

[33] E. Duval, A. Boukenter, and B. Champagnon, "Vibration eigenmodes and size of microcrystallites in glass: observation by very-low-frequency Raman scattering," Physical Review Letters, vol. 56, no. 19, pp. 2052-2055, 1986.

[34] Y. Shapira, "Ultrasonic behavior near the spin-flop transitions of hematite," Physical Review, vol. 184, no. 2, pp. 589-600, 1969.

[35] I. R. Beattie and T. R. Gilson, "The single-crystal Raman spectra of nearly opaque materials. Iron(III) oxide and chromium(III) oxide," Journal of the Chemical Society A, pp. 980-986, 1970.

[36] D. L. A. de Faria, S. Venâncio Silva, and M. T. De Oliveira, "Raman microspectroscopy of some iron oxides and oxyhydroxides," Journal of Raman Spectroscopy, vol. 28, no. 11, pp. 873-878, 1997.

[37] D. Bersani, P. P. Lottici, and A. Montenero, "Micro-Raman investigation of iron oxide films and powders produced by solgel syntheses," Journal of Raman Spectroscopy, vol. 30, no. 5, pp. 355-360, 1999.

[38] O. N. Shebanova and P. Lazor, "Raman study of magnetite $\left(\mathrm{Fe}_{3} \mathrm{O}_{4}\right)$ : laser-induced thermal effects and oxidation," Journal of Raman Spectroscopy, vol. 34, no. 11, pp. 845-852, 2003.

[39] A. Turković, M. Ivanda, V. Vraneša, and A. Drašner, "Raman spectroscopy of thermally annealed $\mathrm{TiO}_{2}$ thin films obtained by chemical vapour deposition and the spray method," Vacuum, vol. 43, no. 5-7, pp. 471-473, 1992.

[40] S. Musić, M. Gotić, M. Ivanda et al., "Chemical and microstructural properties of $\mathrm{TiO}_{2}$ synthesized by sol-gel procedure," Materials Science and Engineering B, vol. 47, no. 1, pp. 33-40, 1997.

[41] I. G. Austin, "Polaron conduction in disordered 3d oxides," Journal of Non-Crystalline Solids, vol. 2, pp. 474-483, 1970. 

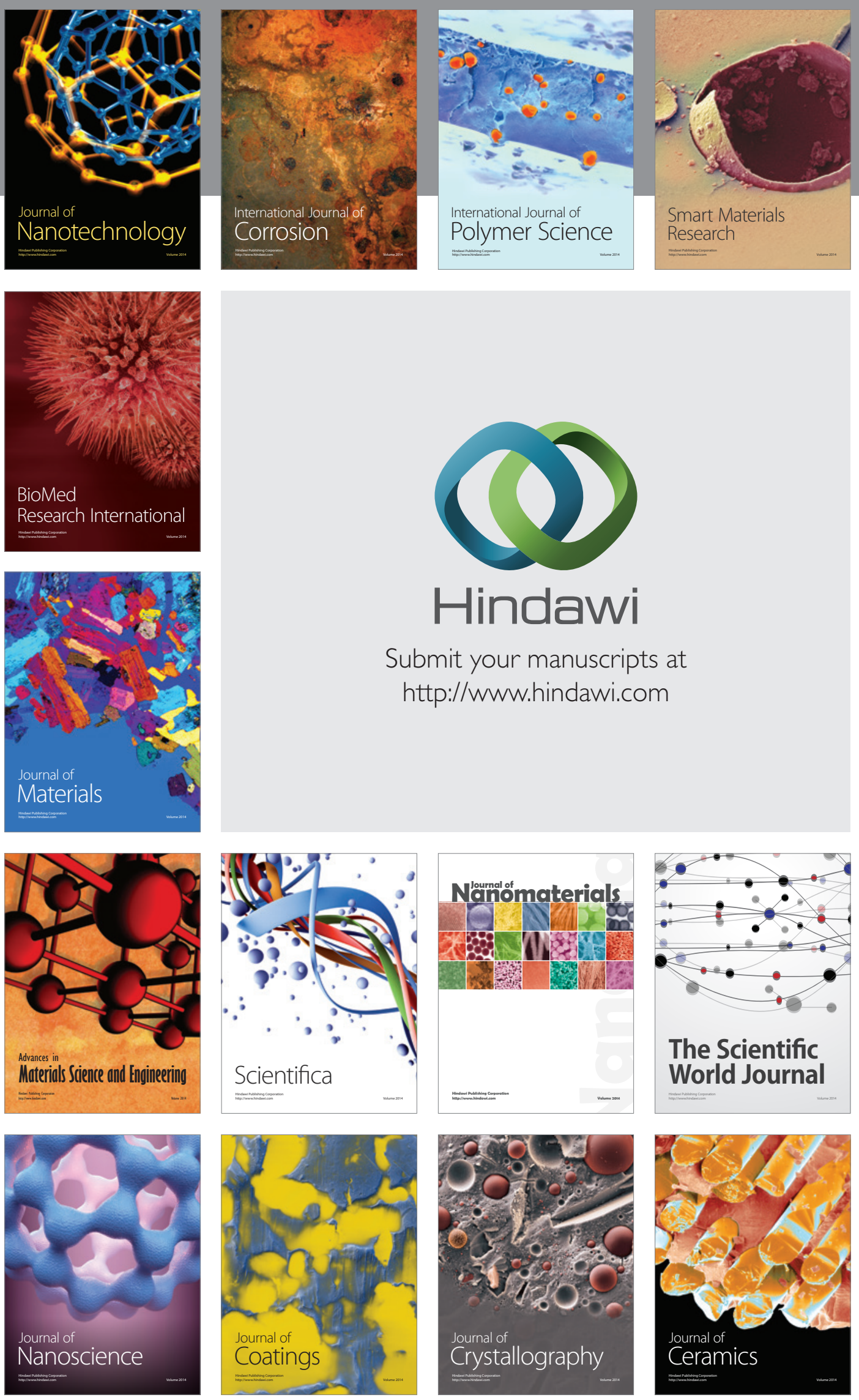

The Scientific World Journal

Submit your manuscripts at

http://www.hindawi.com

\section{World Journal}

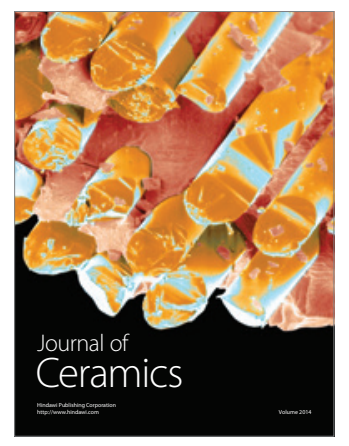

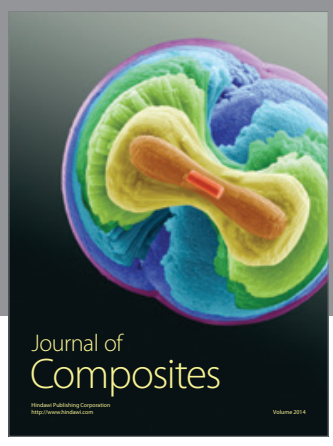
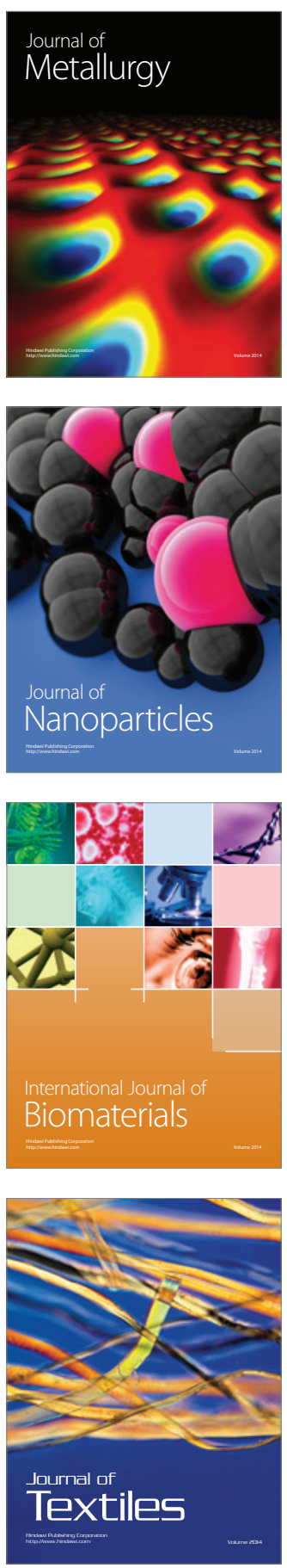